Marquette University

e-Publications@Marquette

$1-1-2006$

\title{
Institutional Characteristics and Gender Choice in IT
}

Mary Malliaris

Loyola University Chicago

Linda Salchenberger

Marquette University, linda.salchenberger@marquette.edu

Published version. "Institutional Characteristics and Gender Choice in IT," in Encyclopedia of Gender and Information Technology. Ed. Eileen Trauth. Hershey, PA: IGI Global, 2006: 813-819. Publisher link. (C) 2006, IGI Global, www.igi-global.com. Posted by permission of the publisher. Linda Salchenberger was affiliated with Northwestern University at the time of publication. 


\section{Institutional Characteristics and Gender Choice in IT}

Mary Malliaris

Loyola University Chicago, USA

Linda Salchenberger

Northwestern University, USA

\section{INTRODUCTION}

While the issue of attracting women to information technology professions has been studied extensively since the 1970s, the gender gap in IT continues to be a significant social and economic problem (Thom, 2001). Numerous research studies have been conducted to understand the reasons for the gender gap in IT (Gurer \& Camp, 2002; Sheard, Lowe, Nicholson, \& Ceddia, 2003; von Hellens, Nielsen, \& Beekhuyzen, 2004). Universities and colleges have developed a variety of programmatic efforts to apply gender gap research results, implementing strategies that increase female undergraduate enrollment in computer science programs (Wardle \& Burton, 2002). Yet, individual successes have not translated into any significant change in the overall percentages of women choosing IT. An analysis of current choices of women in their selection of four-year undergraduate institutions reveals yet another alarming trendyoung women are not choosing to study IT at the traditional academic four year institutions that would best prepare them for the IT professional careers of the future.

To complicate matters, the information technology job market is changing rapidly. For example, some well-documented IT trends that are causing such shifts are outsourcing, the commoditization of IT, the effect of the dot com bust on the job market, and most importantly, the integration of IT into the fundamental economic, social and cultural fabric of our society. IT now permeates every aspect of professional work, even the traditional female-oriented occupations such as nursing and teaching. This integration of IT into the professions must guide the development of a new set of strategies to insure that women have equal opportunities and access to the benefits of an education that prepares them for professional careers. It is in the best interest of the IT profession and our society in general to help young women make choices that include the pursuit of information technology.

\section{BACKGROUND}

The under representation of women in IT is a critical issue of equity and access for women due to the pervasiveness of computing in our society, the many economic opportunities afforded those who have technology skills and knowledge, and value of diversity for this profession (Cohoon, 2003). Although job opportunities in technology companies and technology-oriented industries have recently declined, the need for advanced technology skills in mainstream business careers and entrepreneurship remains critical (Thibodeau \& Lemon, 2004). Nearly $75 \%$ of future jobs will require the use of technology, 8 of the 10 fastest growing occupations between 2000 and 2010 will be computer-related. The annual mean salary for computer and technology occupations remains significantly above average compared to all occupations (U.S. Department of Labor, 2004). Thus, the IT gender gap translates into salary and employment inequities.

Table 1 shows that in 1996, women were $41 \%$ of the IT workforce compared to $34.9 \%$ in 2002 , yet they accounted for $46 \%$ and $46.6 \%$ of the overall workforce in 1996 and 2002, respectively. Note that, in 1996 and 2002, the higher percentage of females was due largely to greater numbers of women in Data Entry and Computer Operator positions, jobs that required less formal education and experience, and provide lower pay. In fact, in both years, women 
Table 1. Women in the IT workforce vs. overall workforce (1996 and 2002)

\begin{tabular}{|l|c|c|c|c|c|}
\hline 2002 Total & 2002 & \multicolumn{2}{|c|}{2002} & \multicolumn{2}{|c|}{1996} \\
\hline $\begin{array}{l}\text { Employed } \\
\text { (thousands) }\end{array}$ & Total & $\begin{array}{c}\% \\
\text { Men }\end{array}$ & $\begin{array}{c}\% \\
\text { Women }\end{array}$ & $\begin{array}{c}\% \\
\text { Men }\end{array}$ & $\begin{array}{c}\% \\
\text { Women }\end{array}$ \\
\hline $\begin{array}{l}\text { Electrical } \\
\text { and } \\
\text { electronic } \\
\text { engineers }\end{array}$ & 677 & 89.7 & 10.3 & 92 & 8 \\
\hline $\begin{array}{l}\text { Computer } \\
\text { systems } \\
\text { analysts and } \\
\text { scientists }\end{array}$ & 1.742 & 72.2 & 27.8 & 72 & 28 \\
\hline $\begin{array}{l}\text { Operation } \\
\text { and systems } \\
\text { researchers } \\
\text { and analysts }\end{array}$ & 238 & 51.3 & 48.7 & 57 & 43 \\
\hline $\begin{array}{l}\text { Computer } \\
\text { programmers }\end{array}$ & 605 & 74.4 & 25.6 & 69 & 31 \\
\hline $\begin{array}{l}\text { Computer } \\
\text { operators }\end{array}$ & 301 & 53.2 & 46.8 & 40 & 60 \\
\hline $\begin{array}{l}\text { Data entry } \\
\text { keyers }\end{array}$ & 595 & 18.3 & 81.8 & 15 & 85 \\
\hline $\begin{array}{l}\text { Total IT } \\
\text { occupations }\end{array}$ & 4,158 & 65.1 & 34.9 & 59 & 41 \\
\hline $\begin{array}{l}\text { All } \\
\text { Occupations }\end{array}$ & 136,485 & 53.4 & 46.6 & 54 & 46 \\
\hline
\end{tabular}

Source: Bureau of Labor Statistics

account for over $81 \%$ of the data entry positions. The current lack of women in the IT workforce is in part a consequence of women not choosing IT undergraduate degree programs or dropping out of these majors.

One traditional path into the IT profession is the completion of an undergraduate degree in Information Technology. However, the percentage of undergraduate degrees awarded to women in computer science and information technology as reported by the National Center for Education Statistics has declined since 1986 (See Table 2). It is well known that one approach to moving women into IT is through the educational pipeline, that is, motivating young women to explore these career paths early in life and to choose IT degree programs.

Despite the benefits of professional technology careers and the advancements of women in many other fields, little progress has been made in moving women through the educational pipeline in computer science (Camp, 1997). In fact, less than $33 \%$ of participants in computer courses and related activities in high schools are girls (AAUW, 2000).

The extensive literature on this topic (Beyer, Rynes, \& Haller, 2004, Gurer \& Camp, 2002; Klawe $\&$ Leveson, 1995) provides us with many reasons
Table 2. Computer/information science bachelor's degrees awarded

\begin{tabular}{|c|c|c|c|c|}
\hline \multirow[t]{2}{*}{ Year } & \multicolumn{3}{|c|}{ Degrees awarded } & \multirow[b]{2}{*}{$\%$ Women } \\
\hline & Total & Men & Women & \\
\hline 1986 & 42,195 & 27,069 & 15,126 & 35.8 \\
\hline 1987 & 39,927 & 26,038 & 13,889 & 34.8 \\
\hline 1988 & 34,896 & 23,543 & 11,353 & 32.5 \\
\hline 1989 & 30,963 & 21,418 & 9,545 & 30.8 \\
\hline 1990 & 27,695 & 19,321 & 8,374 & 30.2 \\
\hline 1991 & 25,410 & 17,896 & 7,514 & 29.6 \\
\hline 1992 & 24,958 & 17,748 & 7,210 & 28.9 \\
\hline 1993 & 24,580 & 17,629 & 6,951 & 28.3 \\
\hline 1994 & 24,553 & 17,533 & 7,020 & 28.6 \\
\hline 1995 & 24,769 & 17,706 & 7,063 & 28.5 \\
\hline 1996 & 24,545 & 17,773 & 6,772 & 27.6 \\
\hline 1997 & 25,393 & 18,490 & 6,903 & 27.2 \\
\hline 1998 & 27,674 & 20,235 & 7,439 & 26.9 \\
\hline 2000 & 37,388 & 26,914 & 10,474 & 28.0 \\
\hline NOTE: & \multicolumn{2}{|c|}{$\begin{array}{c}\text { Data not available for } \\
1999\end{array}$} & & \\
\hline
\end{tabular}

why IT is not attractive to young women. Potential causes include: unsupportive academic environment, the perception of computing as a male-oriented profession, gender differences in how students assess their own performance, lack of role models and insufficient critical mass of female students and faculty to build community.

Colleges and universities face additional challenges in recruiting women. Because of the pipeline issue, women are often less experienced in computing when they enter college, computer science department cultures and software are typically maleoriented and don't appeal to women, and there is a lack of visibility regarding the social value of computing that would appeal to women. Furthermore, while some institutions have been successful in recruiting females to undergraduate computer science programs (Fisher \& Margolis, 2002; Roberts, Kassianidou, \& Irani, 2002), the percentage of women in these disciplines for most institutions continues to decline (ITAA, 2002). Cohoon (2001) argues that, based on her investigation of the University of Virginia's CS department, the characteristics and practices of computer science departments affect female retention at the undergraduate level and inherent female characteristics are an insufficient explanation of women's under representation in computer science. In fact, women themselves tell us why they are not choosing IT, often indicating they find IT uninteresting or perceive that it is more difficult academically than other professions such as 
surgery and law (Weinberger, 2004). Individual characteristics and environmental influences are explored to provide a perspective on women in IT in Trauth (2002) in order to better understand women's lack of involvement in IT.

Numerous recommendations to assist educational institutions in attracting women to undergraduate degree programs in IT appear in the extensive body of research on gender and IT (Baum, 1990; Cohoon, 2003; Cuny \& Aspry, 2000; Wardle \& Burton, 2002). Colleges and universities and academic departments that have been successful in increasing the number of women in technology have shared their strategies for recruiting and retaining female undergraduate students (Margolis \& Fisher, 2002). They encourage institutions to establish and fund university programs and policies to expand the recruitment pool, provide a supportive climate with appropriate student services, broaden (not weaken) admission requirements, offer bridge programs, educate parents and teachers on gender issues, expand undergraduate research opportunities, and build supportive communities of learning through role models and mentoring.

Nevertheless, these successes are not widespread and the question of why women are not choosing computing as a major is a question that may benefit from institutional research. Exploring the characteristics of institutions that have been successful in attracting women may help us to better understand the choices that women are making when they do choose to pursue an undergraduate degree in IT.

\section{USING DATA MINING TO DISCOVER WOMEN'S EDUCATIONAL CHOICES}

Data mining refers to a set of techniques used to search large amounts of data for patterns. Rather than specifying a hypothesis, selecting a sample, and performing a test of the hypothesis, data mining instead searches the data for patterns that occur within it. Thus, it is a set of data driven techniques. The knowledge contained within the data set gives shape to the model. Three of the most used data mining techniques are cluster analysis, association analysis, and decision trees. In this analysis, we only used descriptive analysis as a first step in analyzing our data. Descriptive analysis was used to search a large data set for patterns and associations related to educational choices of women.

When a young woman leaves high school for college, she is making a career decision that influences the path she takes for the rest of her life. Not only the choice of major, but also the choice of the institution can have long-lasting effects on the possibilities available thereafter. The following preliminary research study compares institutions where women, in large numbers and in very small numbers, have chosen to concentrate in IT-related majors.

This study uses IPEDS (Institutional Post-Secondary Educational Statistics) data for 2000-2001 . The purpose of this project is to discover factors associated with the type of institutions that have demonstrated success in attracting women to IT programs, using data mining techniques. The comprehensive IPEDS data set contains variables related to characteristics of the institution, including enrollment numbers by academic discipline using a variable called the CIPCODE (Classification of Instructional Program Code) reported by institutions of higher education. CIP codes indicating specializations in information systems, computer science and information technology were used in this study. The number of female students across these IS/IT CIP codes was calculated to give a total for each institution. This sum was divided by the total number of students at the institution, then multiplied by 100 , to generate our target variable: Percent of women in IT/IS at the institution. This yielded a total of 985 institutions for our analysis. Institutions that had missing values on the variables considered, including both Not Reported and Not Applicable, were deleted.

The variables from the IPEDS data that we examined for this study, based on previous studies, included the following sixteen variables: accreditation of the institution, requirement of secondary school GPA for applicants, requirement of test scores for applicants, affiliation of institution, athletic association of the institution, provision of a meal plan, type of calendar system, highest degree offered, whether institution has a hospital, degree of urbanization, region code, on-campus housing, sector of the institution, availability of on-campus jobs, placement services, and variation of tuition. Four- 
Table 3. Characteristics of the top and bottom institutions with respect to female representation in IT programs

\begin{tabular}{|c|c|c|c|}
\hline Group & & Bottom & Top \\
\hline$\%$ Women in IT & & $<.0599$ & $>.7817$ \\
\hline Total in Group & & 119 & 121 \\
\hline Avg \# Students & & 7947 & 4134 \\
\hline Category & & \multicolumn{2}{|c|}{$\%$ in Category } \\
\hline \multirow[t]{4}{*}{ Affiliation } & Private, for profit & 0.0 & 30.6 \\
\hline & $\begin{array}{l}\text { Private, NFP, not } \\
\text { relig. }\end{array}$ & 21.0 & 31.4 \\
\hline & $\begin{array}{l}\text { Private, NFP, } \\
\text { religious }\end{array}$ & 29.4 & 24.0 \\
\hline & Public & 49.6 & 14.0 \\
\hline \multirow[t]{3}{*}{ Highest Degree } & Bachelors & 11.8 & 33.1 \\
\hline & Masters & 49.6 & 37.2 \\
\hline & Doctorate & 38.7 & 29.8 \\
\hline \multirow[t]{2}{*}{ Accredited } & No & 11.8 & 22.3 \\
\hline & Yes & 88.2 & 77.7 \\
\hline \multirow[t]{2}{*}{ Placement } & No & 3.4 & 22.3 \\
\hline & Yes & 96.6 & 77.7 \\
\hline \multirow[t]{2}{*}{ Dorms } & No & 2.5 & 33.9 \\
\hline & Yes & 97.5 & 66.1 \\
\hline \multirow[t]{3}{*}{ GPA Required } & Neither & 5.9 & 25.6 \\
\hline & Recommend & 18.5 & 14.9 \\
\hline & Required & 75.6 & 59.5 \\
\hline \multirow[t]{3}{*}{ Test Required } & Neither & 0.0 & 10.7 \\
\hline & Recommend & 2.5 & 17.4 \\
\hline & Required & 97.5 & 71.9 \\
\hline \multirow[t]{2}{*}{$\begin{array}{l}\text { Ath. Assoc. } \\
\text { Member }\end{array}$} & No & 3.4 & 35.5 \\
\hline & Yes & 96.6 & 64.5 \\
\hline
\end{tabular}

year institutions that offered an undergraduate degree in information technology in 2000-01 composed the data set to be analyzed.

All institutions were sorted by the value of the target variable. The group with the greatest percentage of women majoring in IT/IS areas is hereafter called the top group. The bottom group includes institutions with the smallest number of women majoring in IT/IS areas. In the top group of schools, the proportion of females is $\mathbf{0 . 7 8 \%}$ or higher and there are 121 schools in this category. The bottom group is the set of schools with the lowest female representation, that is, under $.06 \%$ and it contains 119 colleges and universities. Though the sizes of these two groups are about the same, they have very different sets of values on the IPEDS category variables as shown in Table 3 . In our analysis, either we will only focus on those which provided new insights or great contrast between the two groups.

What are the characteristics of institutions that have the greatest percentage of women IT majors in their overall undergraduate population? The vari- ables which show the greatest differences between the groups are: size, affiliation, highest degree offered, accreditation, placement services offered, dorms, athletic association, and entrance requirements. From the data, we observe that $22.3 \%$ of the top group are non-accredited while only $11.8 \%$ of the bottom group are non-accredited. Of the schools with the lowest female representation, $49.6 \%$ are public institutions, $0 \%$ are for profit, $21 \%$ are private, non-profit, nonreligious and $29.4 \%$ are private, nonprofit, religious institutions. For those with the most females in IT, these numbers are $30.6 \%$ public, $31.4 \%$ for profit, $24 \%$ private, nonprofit, nonreligious and $14 \%$ private, nonprofit, religious. Thus, for the group with the best female representation, they break out into fewer publics (14\% vs. $49.6 \%)$ and more private nonreligious institutions $(31.4 \%$ vs. $21 \%$ ). For the bottom group, $97 \%$ of the schools belong to an athletic association, but for the top group, this drops to $64.5 \%$. We also note that $97.5 \%$ of the bottom group offer dormitories, while only $66 \%$ of the top group are schools are residential. The data also shows that $22.3 \%$ of the schools with high representation of women do not offer placement services as compared to $3.4 \%$ for schools with lower numbers of females in IT. Finally, 33\% of the schools that have higher concentrations of women in IT offer nothing higher than a bachelors' degree, while $88.2 \%$ in the group not chosen by women offer masters' and doctoral programs.

Looking at this data in total, we see that the top group institutions tend to be smaller in size, private, and do not offer doctoral degrees. They are less likely to have any athletic association, to require an admissions test or secondary school GPA, or to provide dormitories.

\section{FUTURE TRENDS}

As many of the previous studies examining the gender gap indicate, this is a complex problem and one that requires a comprehensive, yet focused, institutional, and departmental strategy in order to bring about significant change. One critical component that will impact the agenda to increase IT enrollments is the changing face of the IT profession over the next decade. The traditional approaches 
employed must be supplemented with new strategies, addressing future IT trends such as outsourcing, the commoditization of IT, the effect of the dot com bust on the job market, the integration of IT into the fundamental economic, social and cultural fabric of our society, and the cycles of interest in academic areas of the current and future generations of undergraduate students.

There are multiple challenges - understanding why girls and women make the educational choices they do, attempting to change the culture to help them make choices that will prepare them for technology careers, and predict how the IT profession will change in the short run and the long run. In the short run, we see that the global economy and new impetus on IT to deliver business value are changing jobs from those that require traditional programming and software development skills to jobs such as project management and application integration that require teamwork and organizational skills (Thibodeau, 2004). In the long run, we need to design new ways to educate girls and women on the opportunities of using IT in many non-IT professions and engage them in interesting, challenging and meaningful work requiring technology skills. For example, areas such as nursing, teaching, marketing, and human resource management that have a large female professional staff are becoming increasingly IT-oriented. Specific examples are medical informatics in healthcare, customer relationship management in marketing, and meeting the needs of K-12 tech-savvy students.

\section{Table 4. Recommendations for attracting female students to undergraduate IT programs}

- Offer pre-college experiences such as summer technology camps

- Educate local high school counselors and teachers about women and IT careers

- Align 4 year programs with community college programs

- Provide "gap" educational programs to prepare students coming from institutions with different academic standards

- Develop baccalaureate programs that provide the skills needed for today's IT workforce

- Offer an array of ways to major in technologyCS, MIS, IS

- Hire faculty and staff who can provide insights into the variety of IT-related careers

\section{CONCLUSION}

Based on the research presented here, there are several conclusions and consequent recommendations for reducing the gender gap in IT. First and foremost, we need to educate girls and young women while they are in elementary and high school to help them make better choices regarding their future and lives beyond college. The pipeline begins at a very young age. Stereotypes and barriers are established early in life. If they are getting their degrees at unaccredited, non-PhD granting schools, we will not see them at research universities in the future, adding to further decline in the pipeline. Specific recommendations are shown in Table 4 , incorporating what we have learned about the gender issue.

First and foremost, we must provide interventions early in girls' lives through programs that reach them and their teachers, parents, and counselors. If young girls are choosing to attend nontraditional and two-year programs, then we must connect with them at the community college level and align ourselves with these institutions. Aggressive recruiting and then providing "gap education", i.e., classes, workshops or seminars to bridge the gap between their educational background and those of the students who follow a more traditional path is the next recommendation. Finally, the ultimate challenge will come for all IT students as we better align our undergraduate curricula with the skills and knowledge needed to succeed in the next generation of computing.

\section{REFERENCES}

American Association of University Women (AAUW). (2000). Tech-saavy: Educating girls in the new computer age. Washington, DC: AAUW Press.

Beyer, S., Rynes, K., \& Haller, S. (2004). Deterrents to women taking computer science courses. IEEE Society and Technology Magazine, 23(1), 21-28.

Camp, T. (1997). The incredible shrinking pipeline. Communications of the ACM, 40(10), 103-110. 
Cohoon, J. (2001). Toward improving female retention in the computer science major. Communications of the ACM, 44(5), 108-114.

Cohoon J. (2003, May 3-10). Must there be so few? Including women in CS. ICSE '03: Proceedings of the $25^{\text {th }}$ International Conference on Software Engineering (pp. 668-674), Portland, OR.

Cuny, J., \& Aspry, W. (2002) Recruitment and retention of women graduates in computer science and engineering. SIGSCE Bulletin, 34(2), 168-174.

Fisher, A., \& Margolis, J. (2002). Unlocking the clubhouse: The Carnegie Mellon experience. Communications of the ACM, 34(2), 79-83.

Gurer, D., \& Camp, T. (2002). An ACM-W literature review on women in computing. SIGSCE Bulletin, 34(2), 121-127.

Information Technology Association of America. (2003). Report of the ITAA Blue Ribbon Panel on IT Diversity. Presented at the National IT Workforce Convocation, May 5, 2003, Arlington, VA. Retrieved from http://www.itaa.org/workforce/docs/ 03divreport.pdf

Klawe, M., \& Leveson, N. (1995). Women in computing: Where are we now? Communications of the $A C M, 38(1), 29-35$.

Margolis, J., \& Fisher, A. L. (2002). Unlocking the clubhouse: Women in computing. Cambridge, MA: MIT Press.

National Center for Education Statistics. (2001). Digest of Education Statistics. Retrieved from http:/ /nces.ed.gov/pubsearch/pubsinfo.asp?pubid=2002130

Roberts, E. S., Kassianidou, M., \& Irani, L. (2002). Encouraging women in computer science. SIGSCE Bulletin, 34(2), 84-88.

Sheard, J., Lowe, G., Nicholson, A., \& Ceddia, J. (2003). Tackling transition: Exposing secondary school students to tertiary it teaching and learning. Journal of Information Technology Education, $2,165-180$.

Thibodeau, P., \& Lemon, S. (2004, March). R\&D starts to move offshore: Outsourcing evolves beyond low-wage programming jobs. Computerworld, $38(9), 16$.
Thom, M. (2001). Balancing the equation: Where are the women \& girls in science, engineering, and technology. Washington, DC: National Council for Research on Women.

Trauth, E. (2002). Odd girl out: The individual differences perspective on women in the IT profession. Information Technology and People, 15(2), 98-117.

U.S. Department of Labor, Bureau of Labor Statistics. (2004). Tomorrow's jobs. Occupational Outlook Handbook 2004-2005 Edition. Retrieved from http://www.bls.gov/oco/oco2003.htm

U.S. Bureau of Labor Statistics, Employment, and Earnings. (2003). Table \# 619, Employment by Industry: 1980 to 2002. U.S. Census Bureau, Statistical Abstract of the United States, 2003. Retrieved from http://www.census.gov/prod/2004pubs/ 03statab/labor.pdf

U.S. Bureau of Labor Statistics, Employment, and Earnings. (2003). Table \# 620, Employment Projections by Industry: 2000 to 2010. U. S. Census Bureau, Statistical Abstract of the United States, 2003. Retrieved from http://www.census.gov/prod/ 2004pubs/03statab/labor.pdf

von Hellens, L., Nielsen, S., \& Beekhuyzen, J. (2004). An exploration of dualisms in female perceptions of IT work. Journal of Information Technology Education, 3, 103-116.

Wardle, C., \& Burton, L. (2002). Programmatic efforts encouraging women to enter the information technology workforce. SIGSCE Bulletin, 34(2), 27 31 .

Weinberger, C. (2004, Spring). Just ask! Why surveyed women did not pursue IT courses or careers. IEEE Society and Technology Magazine, 23(2), 28-35.

\section{KEY TERMS}

Accredited Institution: Institution that is accredited by national institutional or specialized accrediting agency that establishes operating standards for educational or professional institutions and programs, determine the extent to which the standards are met, and publicly announce their findings. 
Computer Science: Study of data, computation, and information processing, including methodologies, processes, hardware, software, and applications.

Data Mining: Search of large databases for patterns and trends using a variety of techniques implemented by computer software, sometimes referred to as KDD.

Gender Roles: Professional or social roles associated with males or females that are socially acceptable and considered to be the norm.

Gender Studies: Theoretical and empirical work that focuses on gender in society.

Information Technology: The technology associated with information processing, including computer hardware and software used to store, process and transmit data and information.

IPEDS: The Integrated Postsecondary Education Data System (IPEDS), established as the core postsecondary education data collection program for the National Center for Education Statistics, is a system of system of surveys designed to collect data from all primary providers of postsecondary education.
KDD: Knowledge discovery and data mining; finding applicable insights through the analysis of large amounts of data.

Pipeline: Channel that moves an object from start to finish; used metaphorically to represent the number of qualified individuals who move from one stage in the educational process to another.

Private, For-Profit Institution: A private institution in which the agency in control receives compensation other than wages, rent, or other expenses for the assumption of risk.

Private, Nonprofit Institution: A private institution in which the agency in control receives no compensation other than wages, rent, or other expenses for the assumption of risk. These include both independent and those affiliated with religious organizations.

Public Institution: An educational institution whose programs and activities are operated by publicly elected or appointed officials and supported primarily by public funds. 